\title{
A genetic link between light response and multicellular development in the bacterium Myxococcus xanthus
}

\author{
Francisco J. Nicolás, Rosa $M^{a}$ Ruiz-Vázquez, and Francisco J. Murillo ${ }^{1}$ \\ Departamento de Genética y Microbiología, Facultad de Biología, Universidad de Murcia, Apdo. 4021-30071 Murcia, Spain
}

The Gram-negative bacterium Myxococcus xanthus responds to blue light by producing carotenoid pigments ( $\mathrm{Car}^{+}$phenotype). Genes for carotenoid synthesis lie at two unlinked chromosomal sites, the carC and the carBA operon, but are integrated in a single "light regulon" by the action of common trans-acting regulatory elements. Three known regulatory genes are grouped together at the (light-inducible) carQRS operon. By screening the Car phenotype of a large collection of transposon-induced mutants, we have identified a new car locus that has been named carD (carD1 for the mutant allele). The carD gene product plays a critical role in the light regulon, as it is required for activation of the carQRS and $c a r C$ promoters by blue light. The $c a r D 1$ mutant is impaired in the (starvation-induced) developmental process that allows $M$. xanthus cells both to form multicellular fruiting bodies and to sporulate. Our results indicate that the car $D$ gene product is also required for the expression of a particular set of development-specific genes that are normally activated through the action of intercellular signals.

[Key Words: Blue light; gene regulation; carotenoid genes; Myxobacteria; multicellular development; cell interactions.]

Received March 7, 1994; revised version accepted July 18, 1994.

Blue light modulates various physiological processes both in prokaryotic and eukaryotic microorganisms (Senger 1987). Little is known about the molecular mechanisms for reception and transduction of the light signal, but in a few cases the action of light has been associated with differential gene expression. This is well illustrated by the responses to light of the bacterium Myxococcus xanthus (see below), and the fungus Neurospora crassa. In the latter, both asexual differentiation and the synthesis of carotenes are regulated by blue light, which has been shown to transcriptionally activate several genes related to both processes (Nelson et al. 1989; Sommer et al. 1989; Schmidhauser et al. 1990; Lauter and Russo 1991; Lauter et al. 1992).

$M$. xanthus belongs to a group of Gram-negative, nonphotosynthetic bacteria that can communicate intercellularly (Kaiser and Losick 1993). This ability allows them to respond to starvation conditions by building complex multicellular structures (fruiting bodies) where the vegetative cells differentiate into forms of resistance or myxospores. (For a recent compilation on the myxobacteria, see Dworkin and Kaiser 1993.) M. xanthus responds to illumination with blue light by producing carotenoids, which are known to play a protective role against photochemically generated oxidants (Rau 1988;

\footnotetext{
${ }^{1}$ Corresponding author.
}

Bensasson et al. 1993). The study of this response by genetic and molecular means has revealed a complex network of regulatory actions that are set in motion by blue light and activate the carotenoid genes. This network (the light regulon) is outlined in Figure 1 (for review, see Hodgson and Murillo 1993).

All but one of the genes for carotenoid synthesis in $M$. $x$ anthus are grouped together in a single, light-activated operon (the $\operatorname{car} B A$ operon) in which the genes necessary for the synthesis of phytoene (the first $\mathrm{C}_{40}$ carotene precursor) are included, as well as the genes necessary for other steps downstream in the pathway. The unlinked gene $\operatorname{car} C$ encodes the enzyme that acts in the conversion of phytoene into neurosporene and is also activated by light at the transcriptional level. Contrary to that which happens with the $\operatorname{car} B A$ operon, the light induction of $\operatorname{car} C$ takes place only when the cells enter the stationary phase or are starved of carbon (Fontes et al. 1993; Ruiz-Vázquez et al. 1993).

The effect of light on the expression of the carotenoid genes is mediated by the action of four regulatory genes. Three of them, carQ, carR, and carS, are grouped together, in that order, in a single operon that is also activated transcriptionally by light. This operon is unlinked to the structural genes. Gene carR encodes a membranespanning protein and thus, might participate in the reception of the light signal. Lack-of-function mutations in $\operatorname{car} R$ cause the light-independent expression of all 


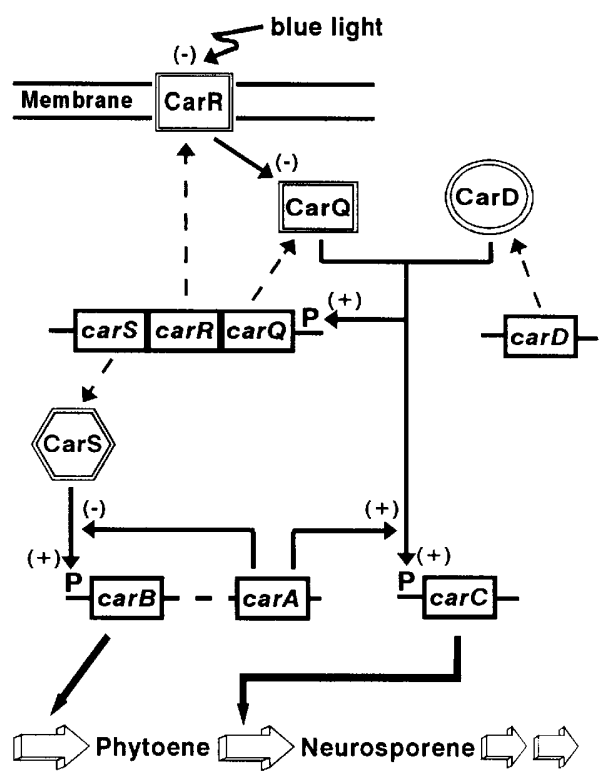

Figure 1. The light regulon of $M$. xanthus. Four unlinked loci (carQRS, carD, $\operatorname{car} B A$, and $\operatorname{car} C$ ) are represented. Discontinuous arrows connect some genes with their gene products. Continuous arrows indicate negative $[(-\|]$ or positive $[\mid+\|]$ effects on gene products or promoters $(\mathrm{P})$. Blue light deactivates the membrane-bound protein CarR; therefore protein CarQ can stimulate the promoters of $\operatorname{car} Q R S$ and $\operatorname{car} C$ through interaction with CarD. Activation of the carQRS operon results in high expression of CarS, which activates the promoter of the carBA operon. This operon contains several structural genes and the regulatory gene $\operatorname{car} A$. This somehow mediates activation of the $\operatorname{car} B$ and the $\operatorname{car} C$ promoters. The product of $\operatorname{car} B$ participates in the synthesis of the first $C_{40}$ precursor, phytoene. This is converted into neurosporene (the first colored carotene) by the product of carC. Further processing of neurosporene depends on other car genes that are located between $\operatorname{car} B$ and $\operatorname{car} A$ and that form a single operon with these two genes. References for this model are indicated in the introductiory section. The identity of $\operatorname{car} D$ and the interaction of CarD with CarQ to activate the carQRS and $\operatorname{car} C$ promoters are inferred from results included in this paper.

known car loci (the carQRS and $\operatorname{car} B A$ operons, and the carC gene), thus leading to the constitutive production of carotenoids. Lack-of-function mutations in carQ, which are epistatic over the carR mutations, have the opposite effect. They result in none of the car loci being activated by light and, therefore, in lack of carotenoid production. Lack-of-function mutations at gene carS block specifically light induction of the car $B A$ operon (Martínez-Laborda et al. 1986; Martínez-Laborda and Murillo 1989; Fontes et al. 1993; Hodgson 1993; McGowan et al. 1993). The fourth regulatory gene, $\operatorname{car} A$, forms a part of the car $B A$ operon. It is defined by mutations that map at the $3^{\prime}$ region of the gene cluster and have a dual effect on the light regulon. These mutations result in the light-independent expression of the carBA operon at a high level and are epistatic over the carQ mutations. The carA mutations also result in the re- duced activation of carC by light (Martínez-Laborda and Murillo 1989; Fontes et al. 1993).

All indicated data lead to the model of Figure 1. In the dark, protein CarR blocks the action of CarQ; therefore, the carQRS operon is expressed at a low level. Light inactivates protein CarR, and CarQ is free (or active) to stimulate the expression of the carQRS operon. This results in a sufficient level of protein CarS being accumulated to activate the carBA operon. Data to be discussed here indicate that CarQ also activates gene carC. The action of CarQ and CarS on the car promoters is somehow mediated by the action of $\operatorname{car} A$.

Sequence analysis of the carQRS gene products does not reveal any indication on operational mechanisms, apart from the membrane-spanning domain mentioned above for CarR. In particular, no amino acid stretches homologous to any of the various domains known to participate in the binding of proteins to DNA were detected in either CarQ or CarS (McGowan et al. 1993); thus, the possibility existed that other elements operating in the regulatory network had gone undetected. Therefore, we set about searching for new car genes. Here, we report the identification of a new locus, unlinked to all other car loci, that we have named carD. This locus plays a major role in the light regulon, as its mutations block the light induction of all car genes. Gene carD participates in other regulatory circuits controlling gene expression in $M$. xanthus. The carD mutant cells are blocked at an early stage of fruiting body formation, a phenotype that is associated with the lack of expression in those cells of a particular set of developmentspecific genes.

\section{Results}

A novel mutation in the light response of $\mathrm{M}$. xanthus

Screening was carried out for Car mutations in populations of cells that had been mutagenized randomly with transposon $\mathrm{Tn} 5$ (resistance to kanamycin; $\mathrm{Km}^{\mathrm{R}}$ ). In a set of experiments, the standard strain DK1050 was mutagenized. DK1050 forms yellow colonies in the dark (attributable to an uncharacterized colored compound) that turn red after illumination for $\sim 12 \mathrm{hr}$ or more (attributable to the accumulation of carotenoids). Dark-incubated plates were used to screen $\sim 3000$ independent $\mathrm{Km}^{\mathrm{R}}$ colonies for a constitutive mutant phenotype $\left(\mathrm{Car}^{\mathrm{C}}\right.$, red colonies). The same plates were then illuminated for $24 \mathrm{hr}$ and screened for a negative mutant phenotype ( $\mathrm{Car}^{-}$, yellow colonies). Two Car ${ }^{-}$mutants were detected in these experiments (named MR509 and MR510).

In a second set of experiments, the $\mathrm{Car}^{\mathrm{C}}$ mutant strain MR151 (carR3) was mutagenized. MR151 forms red colonies both in the dark and in the light. About 8000 independent $\mathrm{Km}^{\mathrm{R}}$ colonies were grown in the dark and screened for a yellow phenotype. Eight colonies were detected (named MR500, MR501, and MR503-MR508). All of them remained yellow when grown in the light; therefore, each of the mutants must carry an epistatic $\mathrm{Car}^{-}$ mutation rather than a suppressor mutation of carR3. 
Previously characterized $\mathrm{Car}^{-}$mutations lie at three unlinked genes: car $Q$, which codes for an activator of the carotenoid genes, and $\operatorname{car} B$ and $\operatorname{car} C$, each of which encodes a different enzyme for the synthesis of neurosporene, the first colored carotene precursor (Fig. 1). $\mathrm{Km}^{\mathrm{R}}$ was transduced separately from each of the new $\mathrm{Car}^{-}$ mutants to $M$. xanthus strains carrying a tetracyclineresistant $\left(\mathrm{Tc}^{\mathrm{R}}\right)$ marker at (or closely linked to) one of the car genes indicated. According to the segregation data for $\mathrm{Km}^{\mathrm{R}}$ and $\mathrm{Tc}^{\mathrm{R}}$ (not shown), seven of the new Tn5 insertions were located at $\operatorname{car} B$, and another at $\operatorname{car} C$. However, the $\mathrm{Km}^{\mathrm{R}}$ markers in strains MR508 and MR509 were unlinked to any of the tested car loci. When $\mathrm{Km}^{\mathrm{R}}$ was transduced from MR508 and MR509 back to the parental strain, all checked transductants $(>500)$ were $\mathrm{Car}^{-}$. Therefore, the mutant phenotype was attributable in both cases to the transposon insertion and was not the consequence of secondary mutations.

After in situ replacement of Tn5 by Tn5-132 in MR509, we found the two new car sites to be unlinked to each other (data not shown). The $\mathrm{Tc}^{\mathrm{R}}$ derivative of MR509 was named MR522. Further data to be presented here correspond to the car locus altered in MR509. This locus and its mutant allele were named carD and carD1, respectively, whereas the $\operatorname{Tn} 5$ (Tn5-132) insertion site was named $\Omega$ MR509. We checked for the accumulation of carotenoids and their carotene precursors in MR509, but none was detected either in dark- or in light-grown cultures.

\section{Mutation carDl prevents light activation of the car genes}

Mutation carD1, originally isolated in the $\mathrm{Car}^{+}$strain DK1050, acted epistatically over a $\mathrm{Car}^{\mathrm{C}}$ mutation at $\operatorname{car} R$. When MR151 (carR3) was used as recipient for transduction of $\Omega$ MR509::Tn5, all of the $\mathrm{Km}^{\mathrm{R}}$ transductants showed a $\mathrm{Car}^{-}$phenotype.

The carA mutant strain MR7 (carA1) forms orange colonies in the dark, as carA1 causes constitutive expression of the carotenoid genes present in the carBA operon. This effect, added to the basal expression of $\operatorname{car} C$, causes the formation of some colored carotenes. The end product of the pathway, however, is not accumulated at the high level found in a carR mutant. MR7 colonies turn red in the light because of activation, although at a reduced level, of the carC gene (Martínez-Laborda et al. 1990; see introductory section and Fig. 1). When RMR509:: Tn 5 was transduced into MR7, all $\mathrm{Km}^{\mathrm{R}}$ transductants showed the same orange phenotype as the parental strain in the dark, although none of them turned red with illumination. Thus, carD1 is not epistatic over carA1 for the effect on the carBA operon but seems to block light activation of $\operatorname{car} C$.

$M$. xanthus strains, which carry gene $l a c Z$ fused transcriptionally to the promoter of $\operatorname{carQRS}, \operatorname{car} B$, or $\operatorname{car} C$, have been obtained (Balsalobre et al. 1987; Fontes et al. 1993; Hodgson 1993|. To understand better the function of $c a r D$, mutation carD1 was transferred to each of these strains. The parental strains and their carD1 derivatives were then used for the analysis of $\beta$-galactosidase expression in dark- and light-grown cultures. As seen in Figure 2 , carD1 completely inhibited light activation of all tested promoters. These experiments were repeated with strains that strongly expressed the same set of $1 a c Z \mathrm{fu}-$ sions in the dark, because of the simultaneous presence of a carR mutation. Mutation carD1 also inhibited the light-independent expression of the tested promoters that is normally found in a carR mutant background (Fig. 2). In all of these experiments, carD1 was transduced into the recipient strains by selection of the associate antibiotic resistance marker. Note that all data in Figure
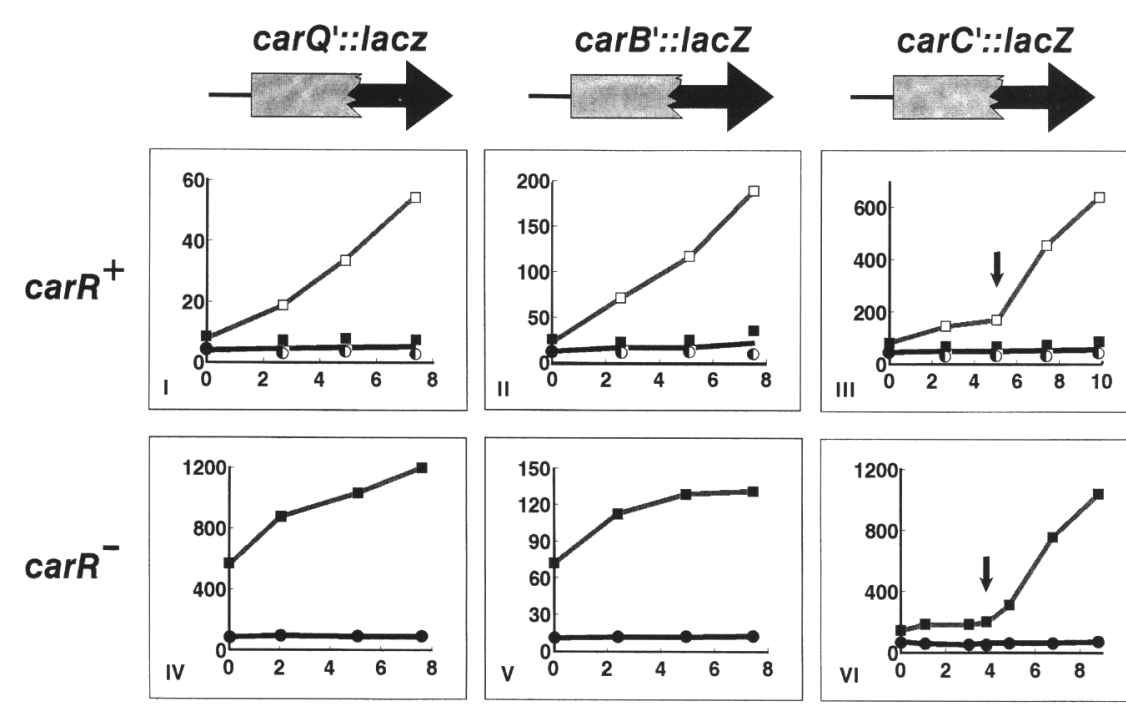

Time (hours)
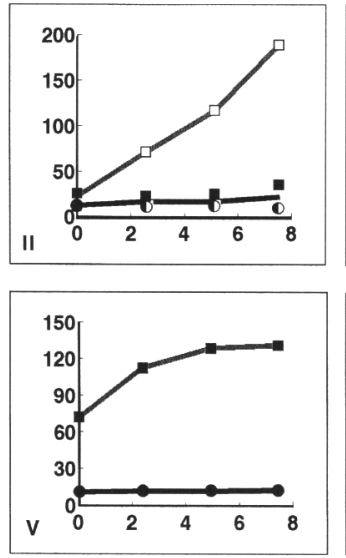

Time (hours)
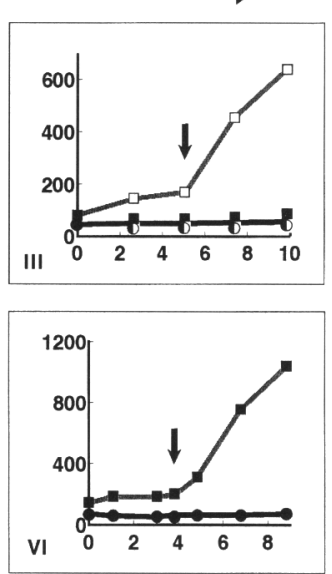

Time (hours)
Figure 2. Effect of a $c a r D$ mutation on the expression of different car genes. At time zero cell samples growing exponentially in the dark were divided in two, one for the dark (closed symbols) and the other for the light (open symbols). Samples in $I I$ and $V I$ were at the late exponential phase and reached the stationary phase at the time indicated by the arrows. Data are $\beta$-galactosidase-specific activities from lac $Z$ transcriptional fusions (arrows at top) to carQ $(I, I V)$, $\operatorname{car} B(I I, V)$, and $\operatorname{carC}(I I I, V I)$. Strains are $(I)$ $\operatorname{MR} 397(\mathbf{\square}, \square)$ and its carD::Tn5-132 derivative $\operatorname{MR} 565(0, O) ;(I I) \operatorname{MR} 418(\boldsymbol{\square}, \square)$ and its car $D:: \operatorname{Tn} 5$ derivative MR518 (O,O); and (III) MR553 (a, $\square)$ and its carD::Tn5-132 derivative MR583 (O,O); (IV) MR398 (D) and its carD::Tn5-132 derivative MR566 (O); (V) MR406 (D) and its carD::Tn5-132 derivative MR559 (O); and (VI) MR555 (ロ) and its carD::Tn5-132 derivative MR582 (O). $I V-V I$ are with dark-grown samples only. 
2 were obtained with a randomly picked colony from $>50$ sib transductants. All exhibited the same behavior when tested on light- or dark-grown X-gal plates, failing to develop the blue color indicative of a significant production of $\beta$-galactosidase.

Because the activation of $\operatorname{car} B$ by light depends on gene carS being expressed at a high level, the negative effect of mutation carD1 on the expression of $c a r B$ could be attributable to the reduced expression of carQRS. Mutant conditions are known in which transcription of $\operatorname{car} B$ does not depend on light activation of the carQRS operon. One such condition involves the carA1 mutation. Another condition corresponds to the transposon insertion SDK1910::Tn5 (Tn5-132), which is close to, but does not interrupt, the carQRS operon. An outward promoter activity in the IS50L element at the end of the transposon results in carQRS being transcribed at high level in the absence of light. As a consequence, $\operatorname{car} B$ is also expressed at high level in the dark (Balsalobre et al. 1987; Hodgson 1993). In accordance with the epistatic relationship described above, carD1 did not prevent the high expression of $c a r B$ in the dark caused by mutation $\operatorname{car} A 1$; nor did it prevent the IS50L-dependent expression of $c a r Q R S$, or the ensuing high expression level of $\operatorname{car} B$ in the dark (Fig. 3). We should note that this latter experiment was carried out with a different car $D$ mutant allele, named carD2, that behaved exactly as carD1. Allele carD2 is a frameshift mutation generated after cloning the carD locus (to be described below) and is not associated with any antibiotic resistance marker. Therefore, we could use the carD2 mutant strain as recipient for the transduction of the Tn5-lac expression probe at $\operatorname{carB}$ (selecting for $\mathrm{Km}^{\mathrm{R}}$ ) or the insertion $\Omega \mathrm{DK} 1910:: \operatorname{Tn} 5$ 132 (selecting for $\mathrm{Tc}^{\mathrm{R}}$ ), or both. Altogether, our data indicate that the negative effect of a carD mutation on the expression of $c a r B$, in an otherwise wild-type genetic background, is a consequence of the blocking effect of that mutation on the expression of carQRS.

We checked whether lack of carC expression in the carD mutants was also attributable to decreased carQRS expression by testing the effect of the Tn 5 insertion that expresses carQRS constitutively. As shown in Figure 3, mutation carD2 prevented light activation of $\operatorname{car} C$ even in the presence of the indicated $\operatorname{Tn} 5$ insertion. Thus, the negative effect of a carD mutation on car $C$ is not simply a consequence of that mutation reducing the expression of $c a r Q R S$.

\section{Mutation carD1 prevents fruiting body formation and blocks expression of several developmentally activated genes}

As deduced from the microscopic observation of colony edges (not shown), strain MR509 is not strongly impaired in gliding, the motility system that is typical of the myxobacteria and other groups of bacteria (for review, see McBride et al. 1993). MR509 was, however, unable to form the multicellular fruiting bodies built by wild-type cells on starvation plates. Most studies on multicellular development in $M$. xanthus have used DK1622 as the

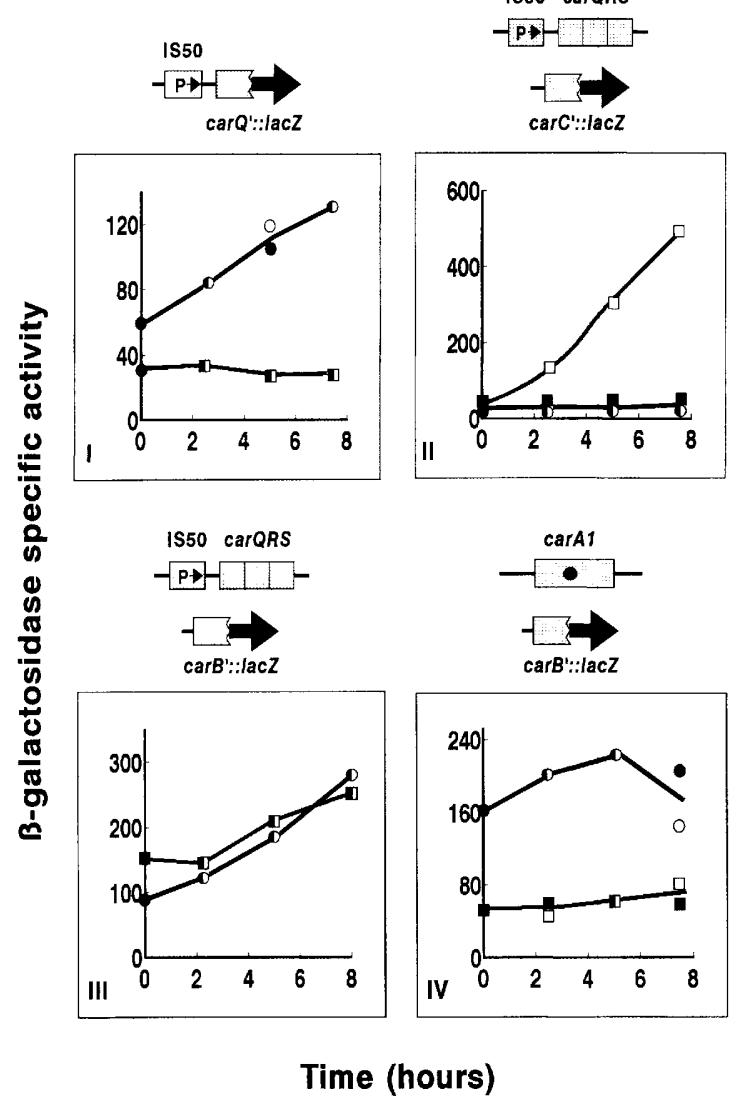

Figure 3. Differential regulation of the $c a r B$ and $c a r C$ promoters. Data and symbols are as in Fig. 2. Drawings at the top depict the car gene that is fused to the $l a c Z$ probe (big arrow) and other relevant features of the corresponding strain. (I) Strain MR609 $(\mathbf{\square}, \square)$ and its carD2 derivative MR610 (O,O); $(I I) \operatorname{MR} 659(\mathbf{\square}, \square)$ and its carD2 derivative MR664 (O,O); (III) MR658(口, $\square)$ and its carD2 derivative $\operatorname{MR} 663(\mathbf{O}, O) ;(I V) \operatorname{MR} 410(\mathbf{\square}, \square)$ and its carD1 derivative MR590(O,O).

standard strain. This is different from, although very closely related to, our standard strain DK1050 (see Materials and methods). Insertion $\Omega M R 509:: \operatorname{Tn} 5$ was transduced into DK1622, and $200 \mathrm{Km}^{\mathrm{R}}$ transductants (all of which showed the expected $\mathrm{Car}^{-}$phenotype) were tested for fruiting. None of them developed normally, indicating that the fruiting defect was attributable to a single mutation and that this was coincident with for very tightly linked to mutation carD1. Figure 4A illustrates the fruiting behavior of DK1622 and one of its carD1 derivatives (MR563). Long after DK1622 had formed mature fruiting bodies, MR563 exhibited only weak signs of cell aggregation, as if it had been blocked at an early stage of development. All sib transductants displayed the same abnormal appearance on starvation plates as did MR563.

The disability of MR563 to develop normally was not a consequence of the lack of carotenoids. We separately transduced different $\mathrm{Car}^{-}$mutations ( $\mathrm{carB}, \mathrm{car} C$, or carQ) and $\mathrm{Car}^{\mathrm{C}}$ mutations (carA or carR) into DK1622. 
A
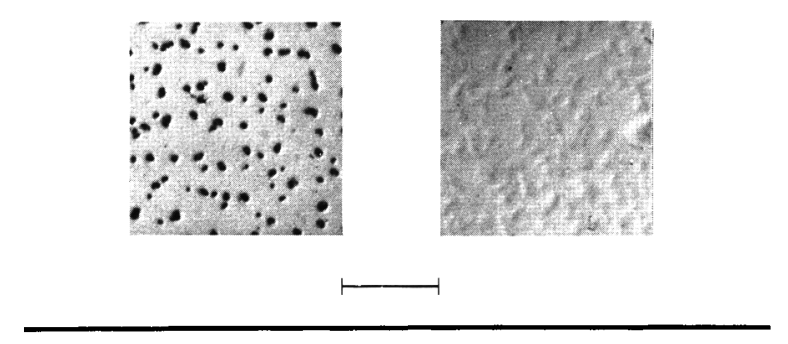

B
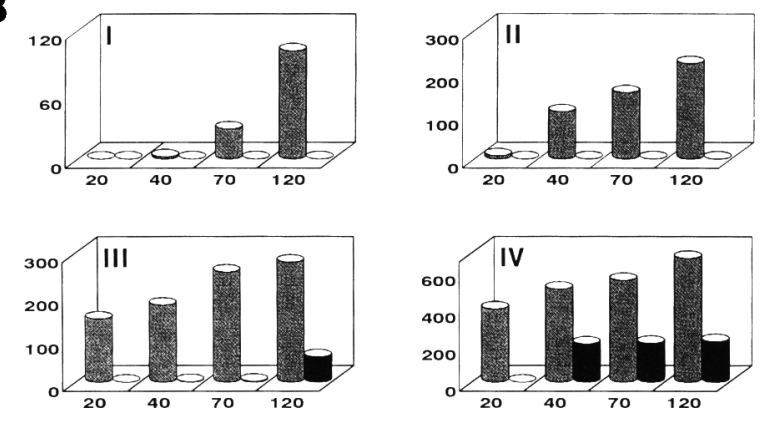

C

\begin{tabular}{ll} 
Mixture & (cells/ml.) \\
\hline MR654 & MR563 \\
\hline $3 \times 10^{8}$ & -
\end{tabular}

$-\quad 8 \times 10^{8}$

$3 \times 10^{8} \quad 3 \times 10^{8}$ $\frac{\text { Sporulation (\%) }}{\text { MR654 MR563 }}$ 100

0.6

2.2

41
Figure 4. (A) Developmental behavior of $M$. xanthus wild-type strain (DK1622, left) and carD1 mutant (MR563, right). Photographs were taken 4 days after the samples $\left(10^{9}\right.$ cells $\left./ \mathrm{ml}\right)$ were spotted on starvation plates. Bar, $2 \mathrm{~mm}$.

(B) Influence of the cell density on the fruiting behavior of DK1622 (gray bars) and MR563 (black bars). Data are the number of fruiting bodies (ordinates) observed at different times (abscissas, in hr) on $10-\mu$ l samples of various cell densities that were spotted on starvation plates. The average of three or more replicas of each sample are represented. $(I) 5 \times 10^{8}$ cells $/ \mathrm{ml}$; $(I I)$ $1.25 \times 10^{9}$ cells $/ \mathrm{ml} ;(I I I) 2.5 \times 10^{9}$ cells $/ \mathrm{ml} ;(I V) 5 \times 10^{9}$ cells $/$ ml. (C) Phenotypic rescue of MR563 by the Fru ${ }^{+}$strain MR654. Cells from each strain were spotted on starvation plates, either alone or in a mixture. The number of spores of one or the other kind were counted after incubation for 6 days. Spores from MR654 (carR3) formed red colonies; those of MR563 formed yellow colonies.

From each transduction, several Car mutant colonies were tested, and they all formed normal fruiting bodies (not shown). The initiation of aggregation in $M$. xanthus depends on cell density (Kuspa et al. 1992). High cell density partially restored the ability of MR563 to form fruiting bodies. However, these were clearly outnumbered by the fruiting bodies formed by control samples of DK1622 (Fig. 4B).

Cell differentiation into myxospores was also affected by mutation carD1. The spores formed by MR563 on starvation plates varied in different experiments $\sim 10^{-3}$ times the number of spores formed by DK1622. MR563 cells recovered their ability to sporulate on starvation plates when mixed with wild-type cells in a 1:1 ratio. Interestingly, the frequency of sporulation of the wildtype cells in the mixture with the carD mutant was lower than that of wild-type cells alone (Fig. 4C). The same effect has been described previously in $M$. xanthus mutants for the production of a factor, called A-factor, that acts as an intercellular signal during development (see below). Glycerol is known to induce the direct transformation of growing cells into myxospores (Dworkin and Gibson, 1964). Mutation carD1 did not affect this aggregation-independent process. The addition of glycerol to exponentially growing cells produced the same number of spores in MR563 as in DK1622 (not shown).

Mutation carD1 prevented the expression of several genes known to be activated specifically during development. To test this, we used 10 different $M$. xanthus strains, each of which has transposon Tn5-lac inserted at a distinct, developmentally activated gene, in the correct orientation for expression of the $l a c Z$ transcriptional probe. $\Omega$ MR509:: Tn5-132 was transduced into each of these strains, and the $\mathrm{Km}^{\mathrm{R}} \mathrm{Tc}^{\mathrm{R}}$ derivatives were used for $\beta$-galactosidase expression analysis. As shown in Figure 5, carD1 affected the developmental activation of seven of the genes tested. In some cases, carD1 blocked activation of the gene completely (Tn5-lac insertions $\Omega D K 4491, \Omega D K 4521, \Omega D K 4403, \Omega D K 4401$, and $\Omega \mathrm{DK} 4435$ |. In other cases, only a partial reduction in developmental activation of the gene was observed ( $\Omega$ DK4514 and $\Omega 4414$ ).

In $M$. xanthus, several genes are known to be responsible for various intercellular signals (called A, B, C, and $\mathrm{D}$ factors) that control the morphological changes and the pattern of differential gene expression observed during fruiting body formation (Kaiser and Kroos 1993). We have found that gene carD lies far from all signaling genes for which a linked selectable marker was available. These were $\operatorname{asg} A$, $a s g B$, and $\operatorname{asg} C$ (A factor), bsgA (B factor), csg $A$ (C factor), and $\operatorname{dsg} A$ ( $\mathrm{D}$ factor). Insertion SMR509::Tn5-132 (or RMR509::Tn5) was transduced into $M$. xanthus strains carrying $\operatorname{Tn} 5$ (or Tn5-132) at a site linked to one of the signaling genes. Segregation for $\mathrm{Km}^{\mathrm{R}}$ and $\mathrm{Tc}^{\mathrm{R}}$ in these crosses showed no evidence of linkage of carD1 to any of the tested loci (data not shown).

\section{A short wild-type DNA fragment rescues the Car and Fru phenotype of the carD mutant}

A 7.0-kb restriction fragment of wild-type DNA astride insertion site $\Omega$ MR509 was cloned in a plasmid vector (pDAH160; $\mathrm{Km}^{\mathrm{R}}$ ) that can be shuttled between Escherichia coli and $M$. xanthus. The chimeric plasmid was named pMAR503. Two other plasmids, carrying internal segments of the 7.0-kb DNA fragment, were named pMAR505 $(3.3 \mathrm{~kb})$ and pMAR513 $(2.8 \mathrm{~kb})$. These plasmids were transduced separately into the carD::Tn5-132 $\left(\mathrm{Tc}^{\mathrm{R}}\right)$ mutant by selecting for $\mathrm{Km}^{\mathrm{R}}$. As the plasmids 

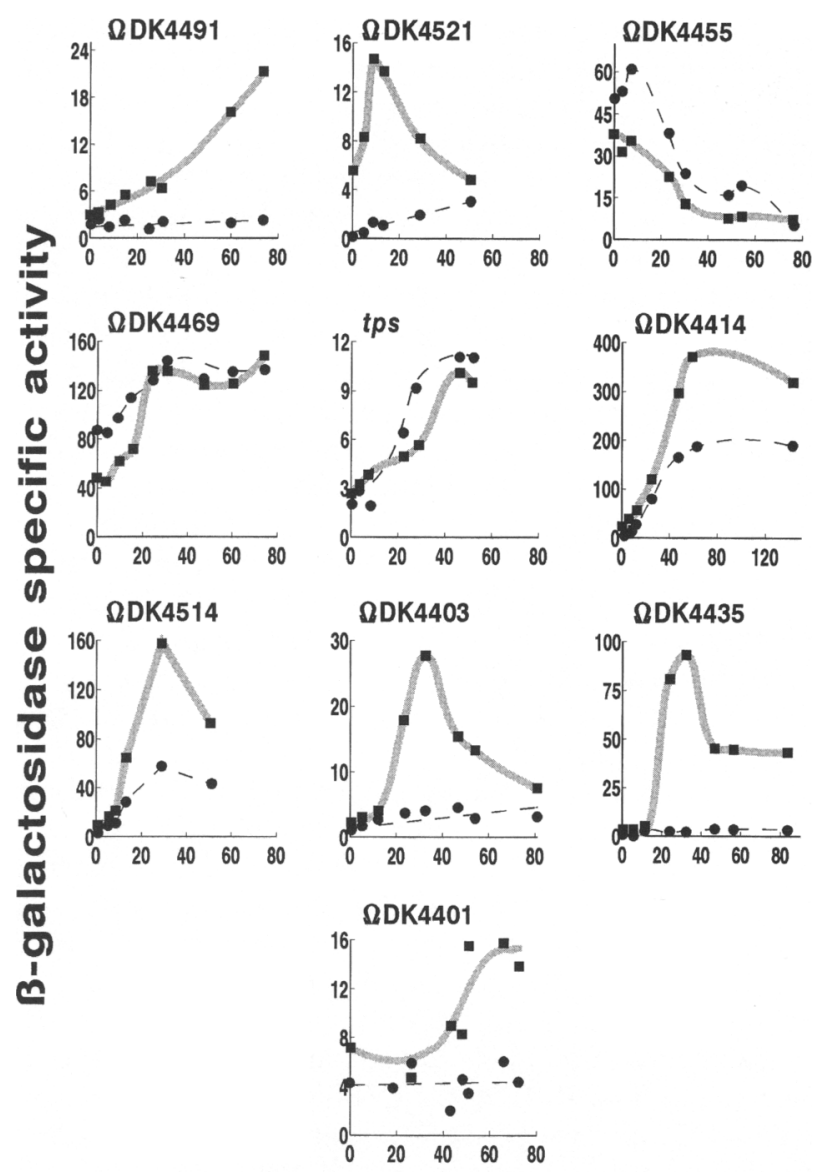

\section{Time (hours)}

Figure 5. Effect of mutation carD1 on the expression of developmentally activated genes. Each panel represents $\beta$-galactosidase production by a strain carrying Tn5-lac inserted at a different developmentally regulated gene ( $\boldsymbol{\square}$, continuous lines), and by the corresponding carD::Tn5-132 derivative $(\mathbf{O}$, broken lines). Time zero indicates the time at which cell samples $\left(\sim 10^{9}\right.$ cells $/ \mathrm{ml}$ ) were spotted on starvation plates. The strains are ordered according to the timing of $\beta$-galactosidase expression (see Fig. 8).

could not replicate in $M$. xanthus cells, transductants arose by integrative homologous recombination. In each case, the Car phenotype of many $\mathrm{Km}^{\mathrm{R}} \mathrm{Tc}^{\mathrm{R}}$ transductants was checked, and the three plasmids were found to complement the carD1 mutation (Fig. 6). A few $\mathrm{Car}^{-}$transductants found with pMAR503 should have originated by gene conversion (Stephens and Kaiser 1987). These results indicated that carD1 was recessive to the corresponding wild-type allele and that the complete carD gene was likely to be contained in pMAR513.

For complementation analysis with portions of the 2.8-kb DNA fragment cloned in pMAR513, we used vector pSJM103. This contains the attachment site $(a t t P)$ of a myxobacterial phage for the efficient integration at a separate locus in the $M$. xanthus chromosome $(a t t B)$. Different portions of the $2.8-\mathrm{kb}$ DNA fragment were cloned in pSIM103 and transduced separately into the carD mutant. The smallest segment that rescued both the Fru and Car phenotype was a $1.2-\mathrm{kb}$ BssHII-NcoI restriction fragment (Fig. 6). No segment was found that could rescue only the Car (or only the Fru) phenotype (not shown).

The expression of carD is regulated developmentally and unaffected by light

The cloning of $\operatorname{car} D$ allowed us to generate the carD2 mutation mentioned above. This was done by cutting plasmid pMAR513 at the sole SacI site within the $M$. xanthus DNA (Fig. 6), followed by exonucleation of the single DNA tails and religation of the newly generated blunt ends. The new plasmid, which probably carries a 4-bp deletion within (or around) $c a r D$, was transduced into strain DK1622, by selecting for $\mathrm{Km}^{\mathrm{R}}$. All of the merodiploid transductants were $\mathrm{Car}^{+} \mathrm{Fru}^{+}$, indicating that a new carD mutation, if present, was also recessive to the wild-type allele. Two $\mathrm{Car}^{+} \mathrm{Fru}^{+}$transductants were grown for 25 generations in the absence of kanamycin, and then plated for $\mathrm{Car}^{-}$segregants. Several $\mathrm{Car}^{-} \mathrm{Km}^{\mathrm{S}}$ colonies were identified from the two cultures and all showed to be $\mathrm{Fru}^{-}$. They must have derived from intramolecular recombination events that resulted in the loss of the vector DNA and of the wild-type allele of $\operatorname{car} D$. We concluded that the SacI site was within gene carD and that a new mutant allele (carD2) had been generated.

We examined the behavior of carD2 in all experimental situations to which carD1 had been subjected. In all cases, carD2 showed exactly the same effects as carD1, with regard to the expression of either the light-activated or development-specific genes. Mutation carD2 was also complemented by the $1.2-\mathrm{kb}$ DNA fragment mentioned above (not shown).

The DNA clones were also used to create $l a c Z$ transcriptional fusions at the same SacI site where mutation carD2 was generated. For this, the proximal SmaI sites at the two sides of SacI were used. The two SmaI-SacI fragments from pMAR503 (Fig. 6) were recloned separately into pDAH274 $\left(\mathrm{Km}^{\mathrm{R}}\right)$, and the orientation of the fragments with respect to the $l a c Z$ probe of the vector was assigned by restriction analysis. Two chimeric plasmids, having $l a c Z$ inserted at the SacI site, each one in a different orientation, were transduced separately into $M$. xanthus strain DK1050. Selected transductants, originated by integrative homologous recombination, should carry a duplication of the cloned DNA and the lacZ probe inserted at the same site, and with the same orientation, as in the incoming plasmid. This is illustrated in Figure 7, which also shows the results of $\beta$-galactosidase expression analysis. In each case, data were obtained using a randomly picked colony from $\geqslant 50 \mathrm{sib}$ transductants that had been checked previously for homogeneous behavior on X-gal plates. In addition to the copy of $c a r D$ that was truncated by the $l a c Z$ probe, all of the transductants were expected to carry a wild-type al- 


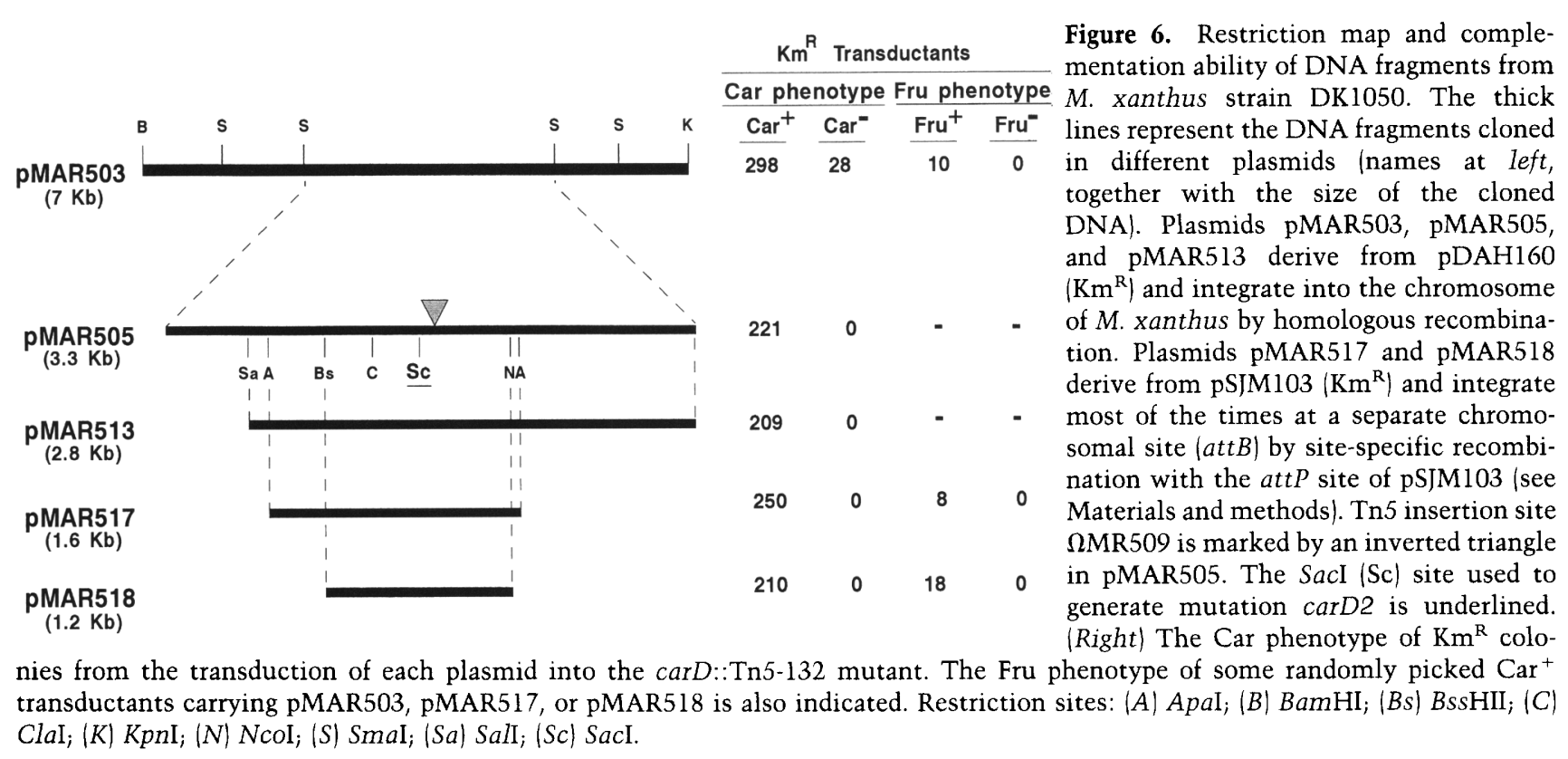

lele of that gene. In agreement with this assumption, they all showed a Car ${ }^{+}$phenotype.

As seen in Figure 7, significant $\beta$-galactosidase activity was only detected in the strain with $1 a c Z$ inserted in a particular orientation (drawn from left to right). Data of $\beta$-galactosidase expression in this strain, which should reveal the expression of gene carD itself, provided evidence for this gene being actively transcribed during the vegetative growth cycle in a light-independent manner. The $c a r D:: 1 a c Z$ fusion was introduced into a $M$. xanthus strain that carried mutation carA1, and in different strains carrying lack-of-function mutations at carQ, $c a r R$, or $c a r S$. None of these mutations produced a significant change in the expression of $\operatorname{car} D$ in the dark or in the light (data not shown).

The carD::IacZ fusion at the SacI site was also transduced into the $M$. xanthus standard strain DK1622. As expected, all tested transductants showed a Car ${ }^{+} \mathrm{Fru}^{+}$ phenotype. Cells of a randomly picked transductant were placed on starvation plates and $\beta$-galactosidase was assayed at different times during development. As shown in Figure 7, carD expression increased quickly after initiation of development and was shut off 5-6 hr later.

\section{Discussion}

The role of carD in the "light regulon" of M. xanthus

Previous studies have attempted to identify and characterize those genes involved in the carotenogenic response of the bacterium $M$. xanthus to blue light (car genes). Our present knowledge of these genes is summarized in the model depicted in Figure 1. This model takes into account the properties and interactions of different car mutations, the results of expression studies using transcriptional fusions to the car promoters, and the se- quence analysis of various car regions (for review, see Hodgson and Murillo 1993).

Here, we describe the screening of 11,000 independent Tn5 insertions into the $M$. xanthus chromosome, during which 10 new carotenoid-less $\left(\mathrm{Car}^{-}\right)$mutants were isolated. Seven of these mutants have the transposon inserted at the previously known gene car $B$. This gene may contain a hot spot for integration of Tn5 (Berg et al. 1983). Another mutant carries Tn5 inserted at the previously known gene carC. The two other $\mathrm{Car}^{-}$strains are affected at new car loci. This study deals with one of the new car loci, named carD.

As we and others have already reported, blue light strongly activates the promoters of the carQRS and carBA operons, and of gene carC (Balsalobre et al. 1987; Fontes et al. 1993; Hodgson 1993; Fig. 1). As deduced from expression analysis of the appropriate lac $Z$ transcriptional fusions, all of these promoters are inactivated when carD is mutated (Fig. 2). This suggests that in the wild type, the carD gene product acts as a positive element at an early stage of the regulatory cascade initiated by the light stimulus.

In the model of Figure 1, it is not known how blue light inactivates the negative regulator CarR, or how this protein blocks the activity of CarQ. It has been proposed, however, that the sensitizer for the light action is protoporphyrin IX (Burchard and Hendricks 1969; McGowan et al. 1993). A role of carD in deactivation of CarR by light is dismissed, given the epistatic effect of carD1 over a mutation at $c a r R$. Instead our data suggest that as proposed for CarQ, the carD gene product is involved directly in the light activation of the carQRS operon. Available data would fit various simple models on how CarQ and CarD interact to turn on the carQRS promoter. For example, one product could act as a transducer of the light signal to activate the other or both could be required to physically assemble at the promoter 


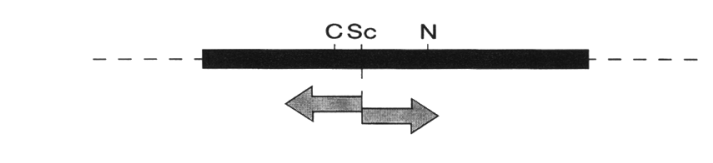

A

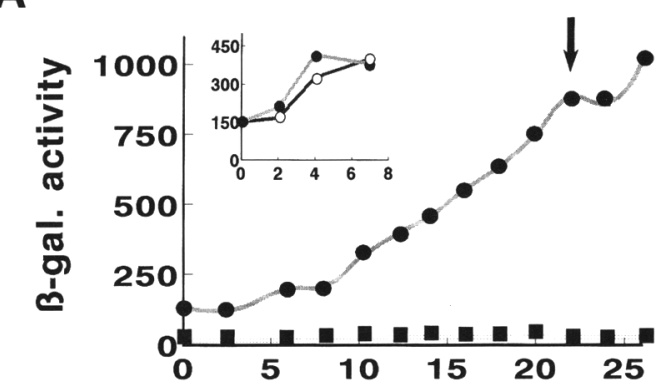

B

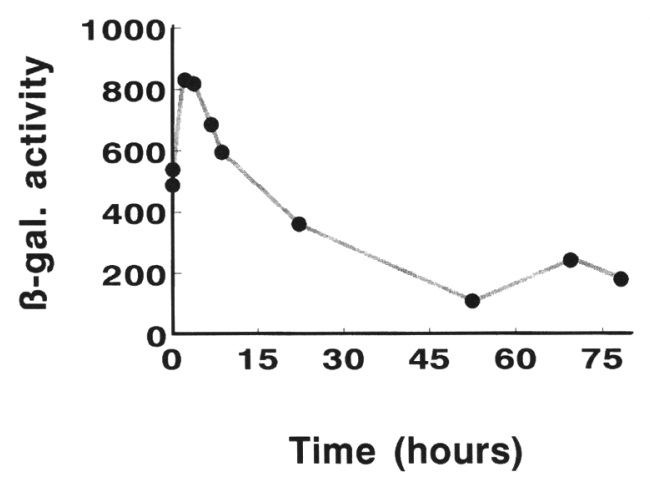

Figure 7. Vegetative and developmental expression of gene carD. (Top) The site of insertion (SacI; Fig. 6) and the orientation of the probe in two lacZ fusions to $c a r D$.

(A) Time course of $\beta$-galactosidase ( $\beta$-gal.) activity in darkgrown cultures of DK1050 derivatives having lacZ inserted from left to right (strain MR624; O), or in the opposite orientation (strain MR625; $\mathbf{0}$ ). Stationary phase was reached at the time indicated by the arrow. (Inset) $\beta$-Galactosidase expression in MR624 growing exponentially in the dark (O) or the light $(O)$. In stationary phase, no differences were observed between darkand light-grown cultures of MR624 (not shown). (B) Developmental expression of $\beta$-galactosidase in the DK1622 derivative carrying the carD::lacZ fusion (strain MR665). At time zero, exponentially growing cells were spotted on starvation plates. At the indicated times, samples were taken for $\beta$-galactosidase analysis.

region. It is worth noting that in analyzing the amino acid sequence of CarQ, McGowan et al. (1993) did not find any of the peptide motifs known to bind DNA. Nor did they find homology between CarQ (or CarR) and the elements of the two-component systems that participate in the response to different environmental signals in various bacterial species (Parkinson and Kofoid 1992).

Mutation carA1 causes constitutive transcription of the $\operatorname{car} B A$ operon and is epistatic over mutations at carQ (Martínez-Laborda and Murillo 1989). The epistasis of carA1 also over the carD1 mutation (Fig. 3) supports the particular arrangement of the carD and carA gene functions in the model of Figure 1. That carD controls the car $B A$ promoter only indirectly is well supported by the null effect of $c a r D 2$ on the expression of $\operatorname{car} B$ when the carQRS operon is transcribed from a constitutive promoter (Fig. 3). It is worth noting that the level of constitutive expression of carQRS is much higher when the carD mutation is present than when it is absent (Fig. 3I). One explanation might be that a factor normally binds at the 5' region of carQRS, thus hampering the run-through of the transcript driven by the constitutive promoter. The carD mutation would prevent that binding.

Constitutive expression of carQRS does not alter the light regulation of the carC promoter (Fig. 3II). Hence, this promoter is unlikely to be activated by the carS gene product in the same way as the $c a r B$ promoter, a conclusion first suggested by other data. A point mutation at car $S$ is known to generate a "superactive" CarS protein, as it causes high expression of $\operatorname{car} B$ in the dark. In addition, lack-of-function mutations at carS block the activity of the carB promoter (Balsalobre 1989; McGowan et al. 1993). None of these carS mutations affect the normal expression of carC (Fontes 1992). We have shown previously that genetic impairment of carQ does block light induction of the carC promoter (Fontes et al. 1993). It seems, then, that CarQ participates in turning on the $\operatorname{carC}$ promoter, but only after being activated by light, probably through deactivation of protein CarR. Light induction of $\operatorname{car} C$ also requires the normal operation of CarD, even when carQRS is expressed in a light-independent manner (Fig. 3II). Hence, CarD and CarQ also appear to interact with each other to activate the carC promoter.

The transcription of the carD gene occurs at a significant level during vegetative growth and is not regulated by light (Fig. 7). This is the first time that this kind of behavior has been recorded among the genes known to be involved in the light response of $M$. xanthus. Consistent with this, carD expression is not altered by mutations at genes $(\operatorname{car} A, \operatorname{car} Q, \operatorname{car} R$, or $\operatorname{car} S)$ that regulate the activity of the light-inducible promoters /see Results). The post-transcriptional regulation of carD by light has not been investigated. Both mutations carD1 la Tn5 insertion) and carD2 (a 4-base deletion) probably generate nonfunctional gene products. The growth rate of the two mutant strains looks normal; therefore, carD seems to be a dispensable gene. Continuous expression of $\operatorname{car} D$, then, may assure a prompt reaction to the light stimulus or may serve other accessory functions.

The role of carD in the developmental program of $\mathrm{M}$. xanthus

Mutation carD1 blocks the fruiting body formation and sporulation that normally occur when $M$. xanthus cells are starved of nutrients (Fig. 4). A simple explanation for this could be that in the wild type, carD participates both in the response to light and in multicellular development. This would imply an unexpected link between the molecular mechanisms for these two processes. Tn 5 mutations may have polar effects (Berg et al. 1980). 
Hence, two distinct, linked genes could be involved in the double mutant phenotype of the carD1 strain. Although this alternative cannot be ruled out completely, we consider it very unlikely for several reasons. A frameshift mutation (carD2) near (upstream of) mutation carD1 also results in a $\mathrm{Car}^{-} \mathrm{Fru}^{-}$phenotype. Mutation carD2 could affect more than one gene, particularly if it had damaged a promoter or a downstream gene were coupled translationally to carD (e.g., see Oppenheim and Yanofsky 1980; Crowell et al. 1987; Tomasiewicz and McHenry 1987). That carD2 does not halt transcription is shown by the positive expression of a lacZ probe inserted at the same site where the mutation was generated (Fig. 7). This expression is activated transiently during development, which also favors the idea of a role of carD in that process. Finally, the $3^{\prime}$ end of the shortest DNA fragment that rescues the double $\mathrm{Car}^{-} \mathrm{Fru}^{-}$phenotype lies only $0.45 \mathrm{~kb}$ downstream of the carD2 mutational site (Fig. 6).

Mutation carD1 blocks fruiting because it prevents the activation of development-specific genes. The genes that we tested (Fig. 5) are part of a larger collection of genes identified by random mutagenesis with Tn5-lac and screening for development-specific expression of $\beta$-galactosidase (Kroos et al. 1986). Tn5-lac insertions in Figure 5 were selected from that collection to form a set of markers distributed uniformly throughout development (Fig. 8).

Developmental gene expression in $M$. xanthus is governed by various extracellular signals (Hagen et al. 1978; Kroos et al. 1986; Kuspa et al. 1986). The absence, by mutation, of a particular signal results in either lack or reduced expression of certain $(\operatorname{Tn} 5-I a c)$ markers. These are then said to exhibit absolute or partial dependence, respectively, on that signal. Four well-characterized signals, the A, B, C, and D factors, are required in various combinations to activate different markers (Kroos and Kaiser 1987; Kaiser and Kroos 1993; Fig. 8). Gene carD is distinct from the known signaling genes. These are three genes for factor $\mathrm{A}$, asgA, asgB, and asgC (Kuspa and Kaiser 1989; Mayo and Kaiser 1989|, and the genes bsgA (Gill and Cull 1986), csgA (Shimkets et al. 1983), and $\operatorname{dsg} A$ (Cheng and Kaiser 1989) for factors B, C, and D, respectively. A locus for a new intercellular signal (esg) has been identified recently. This is also distinct from carD. Contrary to carD1, esg mutations affect the expression of the tps gene (see below), and the restriction map of the carD locus differs from that of esg (Downard et al. 1993).

Comparison of our data with the signal dependence pattern of the Tn5-lac markers leads to various conclusions (see Fig. 8). CarD is unrelated to B- or D-type signaling. Mutation carD1 does not affect expression of early markers $\Omega \mathrm{DK} 4455$ ("partial B") and $\Omega \mathrm{DK} 4469$ ("partial D-partial B"); however, it does block expression of early markers $\Omega$ DK 4491 and $\Omega \mathrm{DK} 4521$, both of which show absolute dependence on factor A. A role for CarD in the production of the A factor itself is unlikely, as the tps gene ("absolute $\mathrm{A}^{\text {") }}$ shows no CarD dependence. This points to the presence of two distinct $\mathrm{A}$ factor-dependent

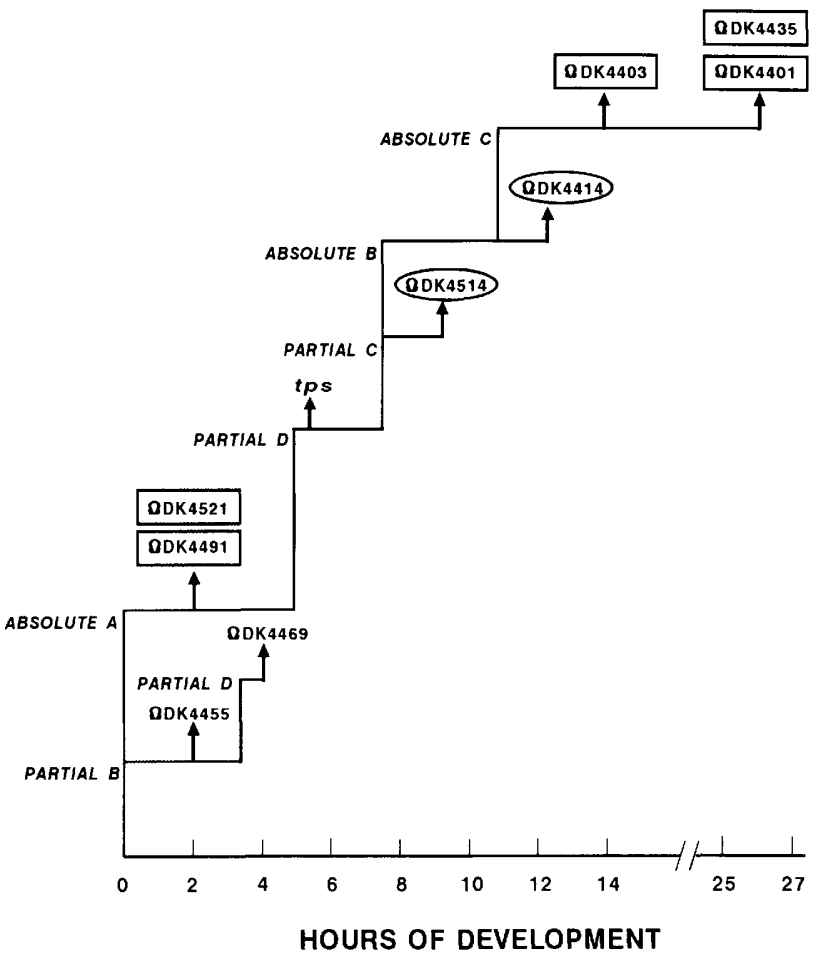

Figure 8. Dependence of developmental markers on A, B, C, and $\mathrm{D}$ factors and on gene carD. [Representation taken from Kroos and Kaiser (1987).] The position of each marker along the $x$ axis indicates the time at which its expression begins during development [for references, see Table 1 ; Kaiser and Kroos (1993) and references therein]. The pattern of dependence of each marker on intercellular factors can be read by following the horizontal and vertical lines to the lower corner of the diagram (see the text for an explanation on partial and absolute dependence). Markers showing absolute dependence on gene carD are enclosed in rectangular frames, whereas those showing partial dependence on gene $c a r D$ are enclosed in elliptical frames (see Fig. 5).

mechanisms for gene activation, one of which requires the participation of CarD.

The CarD-dependence pattern of the other five markers matches their pattern of dependence on the $\mathrm{C}$ factor. "Partial-C" markers $\Omega$ DK4514 and SDK4414 exhibit partial dependence on carD, whereas "absolute- $C$ " markers $\Omega D K 4403, \Omega D K 4401$, and $\Omega D K 4435$, all exhibit absolute dependence on carD (Figs. 5 and 8). Thus, carD may be involved in the generation of the $C$ factor, or it may participate in the $\mathrm{C}$ factor-mediated mechanism for gene activation. These two alternatives are not mutually exclusive, as $\mathrm{C}$ factor regulates its own expression positively (Kim and Kaiser 1991). The faulty production of an intercellular signal would explain the phenotypic rescue of the carD1 mutant at high cell density or when mixed with wild-type cells (Fig. 4).

The effects of mutation carD1 on A factor-dependent markers on the one hand, and on $\mathrm{C}$ factor-dependent markers on the other, are not interconnected. The $\mathrm{C}$ factor-dependent markers that we tested all exhibit abso- 
lute dependence on A factor, but "partial C" markers $\Omega \mathrm{DK} 4514$ and $\Omega \mathrm{DK} 4414$ exhibit only partial dependence on carD (Fig. 8). CarD, then, seems to enter the developmental program separately at two distinct stages, one under the control of the $\mathrm{A}$ factor, and the other of the $\mathrm{C}$ factor. It should be noted that A- and C-type signaling have some features in common. In particular, they are both expressed only after the appropriate cell density has been reached (Kaiser and Kroos 1993).

\section{Final remarks}

The cellular processes in which carD participates, the induction of carotenoid synthesis and multicellular development, are both triggered by external stimuli (light or nutritional deprivation), and both entail the activation of specific genes. Carotenoid gene carC is regulated both by light and carbon starvation (Fontes et al. 1993), but no similar example of cross-regulation is known in the two sets of CarD-dependent genes described here (F.J. Nicolás, R.M. Ruiz-Vázquez, and F.J. Murillo, unpubl.). Thus, in $M$. xanthus, the actions of two different environmental signals converge in a common element (CarD) but diverge in the set of response genes. Specificity results from the interaction of CarD with other elements: CarQ for the light response, and factors $\mathrm{A}$ and $\mathrm{C}$ for the starvation response. More data should be gathered to understand better the action of CarD and to unravel its molecular "tricks". Such data may provide important clues in understanding how myxobacteria sense their environment and how they react to it individually or as a group of cells.

\section{Materials and methods}

\section{Bacterial strains, phages, and growth conditions}

The $M$. xanthus strains used in this study are listed in Table 1 , together with their phenotype, genotype, and origin. The standard strains DK1050 and DK1622 show normal light-induced synthesis of carotenoids $\left(\mathrm{Car}^{+}\right)$and starvation-induced fruiting body formation $\left(\mathrm{Fru}^{+}\right)$. They both derive from the prototype $M$. xanthus strain FB (Kaiser 1979; Ruiz-Vázquez and Murillo 1984). Strains used in the analysis of the light response carried car mutations or lac $Z$ fusions to car genes. The latter were either Tn5-lac-generated fusions (Kroos and Kaiser 1984) or in vitro-constructed gene fusions that were integrated into the $M$. xanthus chromosome by homologous recombination (see below). In both cases, the reporter gene retained the normal translation start signal preceded by stop codons in all three open reading frames; therefore, it produced transcriptional, but not translational fusions. Insertions of transposon Tn5 or Tn5-lac cause $\left(\mathrm{Km}^{\mathrm{R}}\right)$, and insertion of $\mathrm{Tn} 5-132$ causes $\left(\mathrm{Tc}^{\mathrm{R}}\right)$. Insertion sites are identified by $\Omega$ followed by letters and numbers (see Avery and Kaiser 1983).

Media and culture conditions were described previously by Balsalobre et al. (1987). The cells were illuminated exactly as described by Fontes et al. (1993). For generalized transduction between $M$. xanthus strains, phage Mx4-LA27 was used. The phage and the conditions used for transduction of $\mathrm{Km}^{\mathrm{R}}$ and $\mathrm{Tc}^{\mathrm{R}}$ were described by Avery and Kaiser (1983). Coliphage P1 clr-100 cam was used to transfer plasmids from $E$. coli to $M$. xanthus (Gill et al. 1988).

\section{Plasmids}

Cloning vector pDAH160 (Hodgson 1993) carries a $\mathrm{Km}^{\mathrm{R}}$ gene and the incompatibility region of phage $\mathrm{P} 1$ for transfer of the plasmid to $M$. xanthus by $\mathrm{P} 1$-specialized transduction. Those two elements are also present in all other plasmids used in this work. Plasmid pDAH274 (McGowan et al. 1993) carries a lacZ transcriptional probe. Plasmid pSIM103 (McGowan et al. 1993) contains att $P$ of the myxobacterial phage $\mathrm{Mx} 8$. This promotes integration of the plasmid at high frequency by site-specific recombination into a site of the $M$. xanthus chromosome $(a t t B \mid$, which is unlinked to any of the car loci.

Plasmid pDAH217 contains a lacZ transcriptional probe fused to the light-inducible promoter of the carQRS operon (see Fig. 1). As all other plasmids used in this study, pDAH217 cannot replicate in $M$. xanthus cells but can integrate into the $M$. $x$ anthus chromosome by homologous recombination. Integration of pDAH2 17 produces a tandem duplication of the cloned DNA; therefore, a normal copy of the carQRS operon is generated (Hodgson 1993). Plasmid pDAH296 also carries a lacZ probe fused to the promoter region of carQRS. This plasmid, however, contains the IS50L element immediately upstream of the carQRS promoter; therefore the lacZ probe is expressed constitutively when the plasmid is integrated in the $M$. xanthus chromosome. Integration of pDAH296 also leaves a normal copy of the carQRS operon (Hodgson 1993). Plasmid pMAR206 contains a lacZ transcriptional probe fused to the light-inducible promoter of gene carC (Fontes et al. 1993).

\section{DNA manipulation}

The use of plasmid pDAH160 to clone wild-type DNA around a transposon insertion site has been described in detail previously (Hodgson 1993). We used this procedure to obtained plasmid pMAR503, which carries a 7-kb DNA fragment from the $M$. xanthus strain DK1050 (Fig. 6). This and all other plasmids constructed for this study were maintained in the E. coli strain MC1061 (Casadaban and Cohen 1980). Different portions of the DNA cloned in pMAR503 were recloned by using the appropriate restriction enzymes. All nucleic acid and enzymatic manipulations were done according to standard procedures (Maniatis et al. 1982). All enzymes came from Boehringer Mannheim.

\section{Induction of fruiting body formation and sporulation}

For induction of development, exponentially growing cells were washed and resuspended in TPM [10 mM Tris- $\mathrm{HCl}(\mathrm{pH} 7.5), 1$ $\mathrm{mM} \mathrm{KH}_{2} \mathrm{PO}_{4}, 8 \mathrm{mM} \mathrm{MgSO}_{4}$ ), spotted on TPM agar (1.5\%) plates, and incubated at $33^{\circ} \mathrm{C}$. The fruiting bodies formed after different incubation times were counted under a Zeiss dissecting microscope. For counting of spores, the plates were incubated for 6 days and the same number of spots from each sample were scraped from the agar and resuspended in TPM. The spores were counted as temperature- and sonication-resistant colony-forming units (Kuspa and Kaiser 1989). Induction of sporulation in exponentially growing cultures was done by the addition of 0.5 M glycerol, as described by Dworkin and Gibson (1964).

\section{Expression of $\beta$-galactosidase}

Rapid determination of $\beta$-galactosidase production was carried out by examining colony color on plates containing $40 \mu \mathrm{g} / \mathrm{ml}$ of $\mathrm{X}$-gal. Quantitative analysis of $\beta$-galactosidase on dark- or lightgrown liquid cultures was performed as described previously by Balsalobre et al. (1987). Induction by light of the carC promoter 
Table 1. Myxococcus xanthus strains used in this work

\begin{tabular}{|c|c|c|c|}
\hline Strain & Phenotype $^{a}$ & Genotype $^{a}$ & Source or derivation ${ }^{\mathrm{b}}$ \\
\hline \multicolumn{4}{|l|}{ I. } \\
\hline DK 1050 & $\mathrm{Car}^{+} \mathrm{Fru}^{+}$ & & Ruiz-Vázquez et al. (1984) \\
\hline DKl622 & $\mathrm{Car}^{+} \mathrm{Fru}^{+}$ & & Kaiser (1979) \\
\hline MR654 & $\mathrm{Car}^{\mathrm{C}} \mathrm{Fru}^{+} \mathrm{Km}^{\mathrm{R}}$ & $\operatorname{carR3}, \Omega \mathrm{DK} 1611:: \operatorname{Tn} 5$ & F.J. Nicolás (this study) \\
\hline \multicolumn{4}{|r|}{ 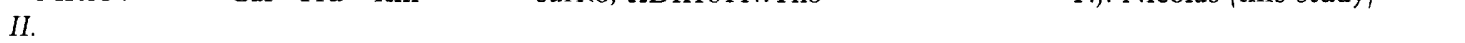 } \\
\hline DK406 & $\mathrm{Car}^{\mathrm{C}}$ & $\operatorname{carR4}$ & Balsalobre et al. (1987) \\
\hline MR7 & $\mathrm{Car}^{\mathrm{C}}$ & $\operatorname{carA1}$ & Balsalobre et al. (1987) \\
\hline MR144 & $\mathrm{Car}^{+} \mathrm{Tc}^{\mathrm{R}}$ & SDK1910::Tn5-132 & Martínez-Laborda et al. (1986) \\
\hline MR151 & $\mathrm{Car}^{\mathrm{C}}$ & $\operatorname{car} R 3$ & Balsalobre et al. (1987) \\
\hline MR397 & $\mathrm{Lac}^{\mathrm{I}} \mathrm{Km}^{\mathrm{R}}$ & $\operatorname{car} Q^{\prime}:: 1 a c Z$ & $\mathrm{pDAH} 217 \times \mathrm{DK} 1050 \rightarrow \mathrm{Km}^{\mathrm{R}}$ \\
\hline MR398 & $\mathrm{Lac}^{\mathrm{C}} \mathrm{Km}^{\mathrm{R}}$ & $\operatorname{car} R 4, \operatorname{car} Q^{\prime}:: 1 a c Z$ & $\mathrm{pDAH} 217 \times \mathrm{DK} 406 \rightarrow \mathrm{Km}^{\mathrm{R}}$ \\
\hline MR401 & $\mathrm{Car}^{-} \mathrm{LacZ}^{\mathrm{I}} \mathrm{Km}^{\mathrm{R}}$ & $\operatorname{car} B:: \operatorname{Tn} 5-1 a c$ & Balsalobre et al. (1987) \\
\hline MR406 & $\mathrm{Lac}^{\mathrm{C}} \mathrm{Km}^{\mathrm{R}}$ & $\operatorname{car} R 3, \operatorname{car} B:: \operatorname{Tn} 5-1 a c$ & Balsalobre et al. (1987) \\
\hline MR410 & $\mathrm{Lac}^{\mathrm{C}} \mathrm{Km}^{\mathrm{R}}$ & carA1, carB::Tn5-lac & Balsalobre et al. (1987) \\
\hline MR418 & $\operatorname{Car}^{-} \mathrm{Lac}^{\mathrm{I}} \mathrm{Tc}^{\mathrm{R}}$ & carB::Tn5-1ac-132 & Martínez-Laborda et al. (1990) \\
\hline MR461 & $\mathrm{Car}^{-} \mathrm{Tc}^{\mathrm{R}}$ & $\operatorname{car} C:: \operatorname{Tn} 5-132$ & Balsalobre et al. (1987) \\
\hline MR553 & $\mathrm{Lac}^{\mathrm{I}} \mathrm{Km}^{\mathrm{R}}$ & $\operatorname{carC}^{\prime}:: 1 a c Z$ & Fontes et al. (1993) \\
\hline MR555 & $\mathrm{Lac}^{\mathrm{C}} \mathrm{Km}^{\mathrm{R}}$ & $\operatorname{carR} 3, \operatorname{car}^{\prime}:: 1 a c Z$ & Fontes et al. (1993) \\
\hline MR609 & $\mathrm{Lac}^{\mathrm{C}} \mathrm{Km}^{\mathrm{R}}$ & IS $50 \mathrm{~L}-\operatorname{car}^{\prime}:: 1 a c Z$ & $\mathrm{pDAH} 296 \times \mathrm{DK} 1050 \rightarrow \mathrm{Km}^{\mathrm{R}}$ \\
\hline MR655 & $\mathrm{Lac}^{\mathrm{I}} \mathrm{Km}^{\mathrm{R}}$ & carB:: Tn5-lac & $\mathrm{MR} 401 \times \mathrm{DK} 1622 \rightarrow \mathrm{Km}^{\mathrm{R}}$ \\
\hline MR658 & $\mathrm{Lac}^{\mathrm{C}} \mathrm{Km}^{\mathrm{R}} \mathrm{Tc}^{\mathrm{R}}$ & carB::Tn5-lac, $\Omega \mathrm{DK} 1910:: \operatorname{Tn} 5-132$ & $\mathrm{MR} 144 \times \mathrm{MR} 655 \rightarrow \mathrm{Tc}^{\mathrm{R}}$ \\
\hline MR656 & $\mathrm{Lac}^{\mathrm{I}} \mathrm{Km}^{\mathrm{R}}$ & $\operatorname{car} C^{\prime}:$ IacZ & pMAR206 $\times$ DK1622 $\rightarrow \mathrm{Km}^{\mathrm{R}}$ \\
\hline MR659 & $\mathrm{Lac}^{\mathrm{I}} \mathrm{Km}^{\mathrm{R}} \mathrm{Tc}^{\mathrm{R}}$ & $\operatorname{carC}^{\prime}:: 1 a c Z, \Omega \mathrm{DK} 1910:: \operatorname{Tn} 5$ & $\mathrm{MR} 144 \times \mathrm{MR} 656 \rightarrow \mathrm{Tc}^{\mathrm{R}}$ \\
\hline \multicolumn{4}{|c|}{ 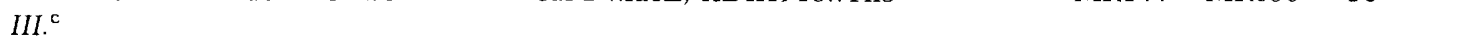 } \\
\hline DK2630 & $\mathrm{Km}^{\mathrm{R}}$ & 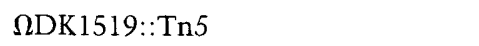 & Shimkets and Kaiser (1982) \\
\hline DK3261 & $\mathrm{Km}^{\mathrm{R}}$ & $\Omega \mathrm{DK} 1867:: \operatorname{Tn} 5$ & Cheng and Kaiser (1989) \\
\hline DK4746 & $\mathrm{Km}^{\mathrm{R}}$ & SDK4678::Tn5 & Mayo and Kaiser (1989) \\
\hline DK5057 & $\mathrm{Km}^{\mathrm{R}}$ & $\Omega \mathrm{DK} 4560:: \operatorname{Tn} 5$ & Kuspa and Kaiser (1989) \\
\hline DK5061 & $\mathrm{Km}^{\mathrm{R}}$ & SDK4561::Tn5 & Kuspa and Kaiser (1989) \\
\hline DK5209 & $\mathrm{Tc}^{\mathrm{R}}$ & bsgA330 & Gill and Cull (1986) \\
\hline \multicolumn{4}{|l|}{ IV. } \\
\hline DK4290 & $\mathrm{Lac}^{\mathrm{D}}$ & $\operatorname{tps}(\Omega 4273):: \operatorname{Tn} 5-1 a c$ & Kroos and Kaiser (1987) \\
\hline DK4293 & $\mathrm{Lac}^{\mathrm{D}}$ & SDK4401::Tn5-lac & Kroos et al. (1986) \\
\hline DK4368 & $\mathrm{Lac}^{\mathrm{D}}$ & $\Omega \mathrm{DK} 4403:: \operatorname{Tn} 5-1 a c$ & Kroos et al. (1986) \\
\hline DK4469 & $\mathrm{Lac}^{\mathrm{D}}$ & SDK4469::Tn5-lac & Kroos et al. (1986) \\
\hline DK4491 & $\mathrm{Lac}^{\mathrm{D}}$ & SDK4491::Tn5-lac & Kroos et al. (1986) \\
\hline DK4514 & $\mathrm{Lac}^{\mathrm{D}}$ & SDK4514::Tn5-lac & Kroos et al. (1986) \\
\hline DK4521 & $\mathrm{Lac}^{\mathrm{D}}$ & RDK4521::Tn5-lac & Kroos et al. (1986) \\
\hline DK5204 & $\mathrm{Lac}^{\mathrm{D}}$ & RDK4435::Tn5-1ac & Kroos et al. (1986) \\
\hline DK5206 & $\mathrm{Lac}^{\mathrm{D}}$ & $\Omega \mathrm{DK} 4455:: \operatorname{Tn} 5-1 a c$ & Kroos et al. (1986) \\
\hline DK5279 & $\mathrm{Lac}^{\mathrm{D}}$ & $\Omega \mathrm{DK} 4414:: \operatorname{Tn} 5-1 a c$ & Kroos and Kaiser (1987) \\
\hline
\end{tabular}

Strains are classified in different groups for clarity: (I) Standards; (II) strains used in the study of the response to light; (III) strains for the analysis of linkage to signaling genes; (IV) strains carrying developmentally regulated Tn5-lac insertions. Strain MR654, a DK1622 derivative, is included in group I because it shows a normal $\mathrm{Fru}^{+}$phenotype and was used here only for the phenotypic complementation of a $\mathrm{Fru}^{-}$mutant (Fig. 4). Other strains are introduced in the text.

${ }^{a}$ Only the phenotypes and genotypes relevant to this work are indicated. (Lac ${ }^{\mathrm{I}}$ ) Light-inducible synthesis of $\beta$-galactosidase; (Lac ${ }^{\mathrm{C}}$ ) high level of $\beta$-galactosidase in the dark and in the light; $\left(\mathrm{Lac}^{\mathrm{D}}\right)$ developmentally induced synthesis of $\beta$-galactosidase. All strains in group II derive from DK1050, unless indicated otherwise in the Source or derivation column. All strains in groups III and IV derive from DK1622.

${ }^{b}$ A brief description is given of the way some strains were constructed for this work. In these cases, the plasmids or strains used as donor of the antibiotic resistance marker are named in the first place.

${ }^{\mathrm{c}}$ Each strain in this group carries Tn5 inserted at a site linked to a distinct signaling gene. The exception is DK5209, which contains the $\mathrm{Tc}^{\mathrm{R}}$-encoding $B g l \mathrm{II}$ fragment from $\mathrm{Tn} 10$ inserted in the $b s g A$ gene (formerly $s s b A$ ).

requires that the cells enter the stationary phase (Fontes et al. 1993). $\beta$-Galactosidase expression in strains carrying a car$C^{\prime}::$ lacZ fusion was induced in cultures at the late exponential phase of growth. Quantitative analysis of $\beta$-galactosidase in developing cells was carried out as described by Kroos et al. (1986). Only the period of sonication on glass beads was modified (for maximum spore breakage), as a different apparatus was used (Braun Labsonic U). Reported data of enzyme-specific activities, given in nanomoles of $o$-nitrophenol produced/min per milligram of protein are the average of three or more independent determinations. Standard deviations never exceed $10 \%$ of the average. 


\section{Acknowledgments}

We especially acknowledge the participation of Elena Cuadrado in the mutagenesis with Tn5 and the screening for new Car mutants. We thank Dale Kaiser, Ivonne Cheng, David A. Hodgson, and Simon J. McGowan for providing strains and plasmids. We also thank José A. Madrid and Ana C. García for technical assistance. This work was supported by the Spanish Dirección General de Investigación Científica y Técnica (grant PB89-0433 and fellowship to F.J.N.).

The publication costs of this article were defrayed in part by payment of page charges. This article must therefore be hereby marked "advertisement" in accordance with 18 USC section 1734 solely to indicate this fact.

\section{References}

Avery, L. and D. Kaiser. 1983. In situ transposon replacement and isolation of a spontaneous tandem genetic duplication. Mol. \& Gen. Genet. 191: 99-109.

Balsalobre, J.M. 1989. "Inducción por la luz de la expresión génica y la carotenogénesis en Myxococcus xanthus." Ph.D. thesis, University of Murcia, Murcia, Spain.

Balsalobre, J.M., R.M. Ruiz-Vázquez, and F.J. Murillo. 1987. Light induction of gene expression in Myxococcus xanthus. Proc. Natl. Acad. Sci. 84: 2359-2362.

Bensasson, R.V., E.J. Land, and T.G. Truscot. 1993. Excited states and free radicals in biology and medicine. Oxford University Press, Oxford, UK.

Berg, D.E., A. Weiss, and L. Crossland. 1980. Polarity of Tn5 insertion mutations in Escherichia coli. I. Bacteriol. 142: 439-446.

Berg, D.E., M.A. Schmandt, and J. Lowe. 1983. Specificity of transposon Tn5 insertion. Genetics 105: 813-828.

Burchard, R.P. and S.B. Hendricks. 1969. Action spectrum for carotenogenesis in Myxococcus xanthus. I. Bacteriol. 97: 1165-1168.

Casadaban, M.J. and S.N. Cohen. 1980. Analysis of gene control signals by DNA fusion and cloning in E. coli. J. Mol. Biol. 138: 179-207.

Cheng, I. and D. Kaiser. 1989. $d s g$, a gene required for cell-cell interaction early in Myxococcus development. J. Bacteriol. 171: 3719-3726.

Crowell, D.N., W.S. Reznikoff, and C.R. Raetz. 1987. Nucleotide sequence of the Escherichia coli gene for Lipid A disaccharide synthase. I. Bacteriol. 169: 5727-5734.

Downard, J., S.V. Ramaswamy, and K.-S. Kil. 1993. Identification of esg, a genetic locus involved in cell-cell signaling during Myxococcus xanthus development. I. Bacteriol. 175: $7762-7770$.

Dworkin, M. and S.M. Gibson. 1964. A system for studying microbial morphogenesis: Rapid formation of microcyst in Myxococcus xanthus. Science 146: 243-244.

Dworkin, M. and D. Kaiser (ed.). 1993. Myxobacteria II. American Society for Microbiology, Washington, D.C.

Fontes, M. 1992. "Estructura y regulación por luz del gen de la deshidrogenasa del fitoeno de la bacteria Myxococcus xanthus." Ph.D. thesis, University of Murcia, Murcia, Spain.

Fontes, M., R.M. Ruiz-Vázquez, and F.J. Murillo. 1993. Growth phase dependence of the activation of a bacterial gene for carotenoid synthesis by blue light. EMBO I. 12: 1265-1275.

Gill, R.E. and M.G. Cull. 1986. Control of developmental gene expression by cell-to-cell interactions in Myxococcus xanthus. J. Bacteriol. 168: 341-347.

Gill, R.E., M.G. Cull, and S. Fly. 1988. Genetic identification and cloning of a gene required for developmental cell inter- actions in Myxococcus xanthus. I. Bacteriol. 170: 52795288.

Hagen, D.C., A.P. Bretscher, and D. Kaiser. 1978. Synergism between morphogenetic mutants of Myxococcus xanthus. Dev. Biol. 64: 284-296.

Hodgson, D.A. 1993. Light-induced carotenogenesis in Myxococcus xanthus: Genetic analysis of the carR region. Mol. Microbiol. 7: 471-488.

Hodgson, D.A. and F.J. Murillo. 1993. Genetics of regulation and pathway of synthesis of carotenoids. In Myxobacteria II (ed. M. Dworkin and D. Kaiser), pp. 157-181. American Society for Microbiology, Washington, D.C.

Kaiser, D. 1979. Social gliding is correlated with the presence of pili in Myxococcus xanthus. Proc. Natl. Acad. Sci. 76: 59525956.

Kaiser, D. and L. Kroos. 1993. Intercellular signaling. In Myxobacteria II (ed. M. Dworkin and D. Kaiser), pp. 257-283. American Society for Microbiology, Washington, D.C.

Kaiser, D. and R. Losick. 1993. How and why bacteria talk to each other. Cell 73: 873-885.

Kim, S.K. and D. Kaiser. 1991. C-Factor has distinct aggregation and sporulation thresholds during Myxococcus development. J. Bacteriol. 173: 1722-1728.

Kroos, L. and D. Kaiser. 1984. Construction of Tn5-lac, a transposon that fuses lac $Z$ expression to exogenous promoters, and its introduction into Myxococcus xanthus. Proc. Natl. Acad. Sci. 81: 5816-5820.

- 1987. Expression of many developmentally regulated genes in Myxococcus depends on a sequence of cell interactions. Genes \& Dev. 1: 840-854.

Kroos, L., A. Kuspa, and D. Kaiser. 1986. A global analysis of developmentally regulated genes in Myxococcus xanthus. Dev. Biol. 117: 252-266

Kuspa, A. and D. Kaiser. 1989. Genes required for developmental signalling in Myxococcus xanthus: Three asg loci. J. Bacteriol. 171: 2762-2772.

Kuspa, A., L. Kroos, and D. Kaiser. 1986. Intercellular signalling is required for developmental gene expression in Myxococcus xanthus. Dev. Biol. 171: 267-276.

Kuspa, A., L. Plamman, and D. Kaiser. 1992. A-signaling and the cell density requirement for Myxococcus xanthus development. I. Bacteriol. 174: 3319-3326.

Lauter, F.-R. and Russo. 1991. Blue light induction of conidiation-specific genes in Neurospora crassa. Nucleic Acids Res. 19: 6883-6996.

Lauter, F.-R., V.E.A. Russo, and C. Yanofsky. 1992. Developmental and light regulation of eas, the structural gene for the rodlet protein of Neurospora. Genes \& Dev. 6: 2373-2381.

Maniatis, T., E.F. Fritsch, and J. Sambrook. 1982. Molecular cloning. A laboratory manual. Cold Spring Harbor Laboratory, Cold Spring Harbor, New York.

Martínez-Laborda, A. and F.J. Murillo. 1989. Genic and allelic interactions in the carotenogenic response of Myxococcus xanthus to blue light. Genetics 122: 481-490.

Martínez-Laborda, A., M. Elías, R.M. Ruiz-Vázquez, and F.J. Murillo. 1986. Insertions of Tn5 linked to mutations affecting carotenoid synthesis in Myxococcus xanthus. Mol. \& Gen. Genet. 205: 107-114.

Martínez-Laborda, A., J.M. Balsalobre, M. Fontes, and F.J. Murillo. 1990. Accumulation of carotenoids in structural and regulatory mutants of the bacterium Myxococcus xanthus. Mol. \& Gen. Genet. 223: 205-210.

Mayo, K.A. and D. Kaiser. 1989. asgB, a gene required early for developmental signalling, aggregation, and sporulation of Myxococcus xanthus. Mol. \& Gen. Genet. 218: 409-418.

McBride, J., P. Hartzell, and D.R. Zusman. 1993. Motility and 
tactic behavior of Myxococcus xanthus. In Myxobacteria II (ed. M. Dworkin and D. Kaiser), pp. 285-305. American Society for Microbiology, Washington, D.C.

McGowan, S.J., H.C. Gorham, and D.A. Hodgson. 1993. Lightinduced carotenogenesis in Myxococcus xanthus: DNA sequence analysis of the $c a r R$ region. Mol. Microbiol. 10: 713735.

Nelson, M.A., G. Morelli, A. Carattoli, N. Romano, and G. Macino. 1989. Molecular cloning of a Neurospora crassa carotenoid biosynthetic gene (albino-3) regulated by blue light and the products of the white collar genes. Mol. Cell. Biol. 9: $1271-1276$.

Oppenheim, D.S. and C. Yanofsky. 1980. Translational coupling during expression of the tryptophan operon of Escherichia coli. Genetics 95: 785-795.

Parkinson, J.S. and E.C. Kofoid. 1992. Communication modules in bacterial signaling proteins. Annu. Rev. Genet. 26: 71112.

Rau, W. 1988. Functions of carotenoids other than in photosynthesis. In Plant pigments (ed. T. Goodwin), pp. 231-255. Academic Press, London, UK.

Ruiz-Vázquez, R.M. and F.J. Murillo. 1984. Abnormal motility and fruiting behavior of Myxococcus xanthus bacteriophageresistant strains induced by a clear-plaque mutant of bacteriophage Mx8. J. Bacteriol. 160: 818-821.

Ruiz-Vázquez, R.M., M. Fontes, and F.J. Murillo. 1993. Clustering and co-ordinated activation of carotenoid genes in $\mathrm{MyxO-}$ coccus xanthus by blue light. Mol. Microbiol. 10: 25-34.

Schmidhauser, T.J., F.R. Lauter, V.E.A. Russo, and C. Yanofsky. 1990. Cloning, sequence, and photoregulation of al-1, a carotenoid biosynthetic gene of Neurospora crassa. Mol. Cell. Biol. 10: $5064-5070$.

Senger, H. (ed.). 1987. Blue light responses: Phenomena and occurrence in plants and microorganisms, vol. 2. CRC Press, Boca Raton, FL.

Shimkets, L.J. and D. Kaiser. 1982. Murein components rescue developmental sporulation of Myxococcus xanthus. I. Bacteriol. 152: 462-470.

Shimkets, L.J., R.E. Gill, and D. Kaiser. 1983. Developmental cell interactions in Myxococcus xanthus and the spoC locus. Proc. Natl. Acad. Sci. 80: 1406-1410.

Sommer, T., J.A.A. Chambers, J. Eberle, F.-R. Lauter, and V.E.A. Russo. 1989. Fast light-regulated genes of Neurospora crassa. Nucleic Acids Res. 17: 5713-5723.

Stephens, K. and D. Kaiser. 1987. Genetics of gliding motility in Myxococcus xanthus: Molecular cloning of the $m g l$ locus. Mol. \& Gen. Genet. 207: 256-266.

Tomasiewicz, H.G. and C.S. McHenry. 1987. Sequence analysis of the Escherichia coli dnaE gene. I. Bacteriol. 169: 57355744 . 


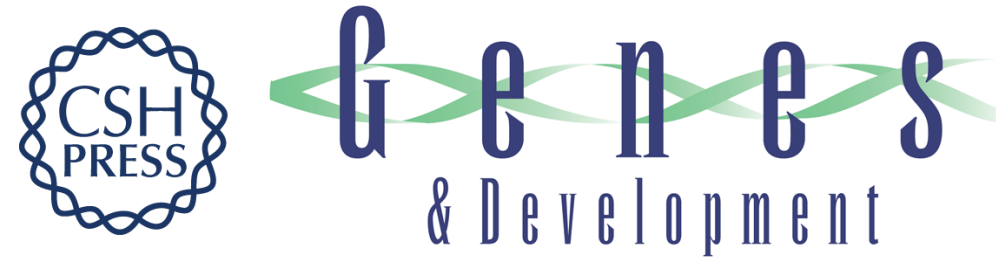

\section{A genetic link between light response and multicellular development in the bacterium Myxococcus xanthus.}

F J Nicolás, R M Ruiz-Vázquez and F J Murillo

Genes Dev. 1994, 8:

Access the most recent version at doi:10.1101/gad.8.19.2375

References This article cites 42 articles, 25 of which can be accessed free at:

http://genesdev.cshlp.org/content/8/19/2375.full.html\#ref-list-1

License

Email Alerting

Service

Receive free email alerts when new articles cite this article - sign up in the box at the top right corner of the article or click here.

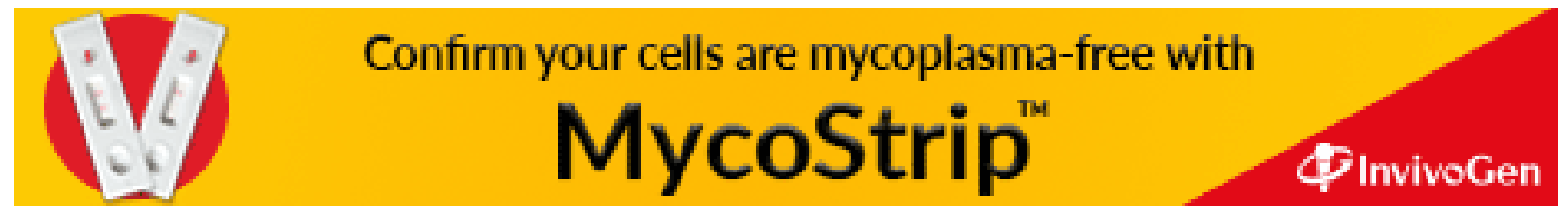

